Special issue of the 3rd International Conference on Computational and Experimental Science and Engineering (ICCESEN 2016)

\title{
The Investigation of Radionuclide Concentrations in Soil and Lifetime Cancer Risk Due to Gamma Radioactivity in Zonguldak, Turkey
}

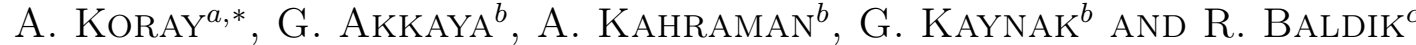 \\ ${ }^{a}$ Ereğli Education Faculty, Bülent Ecevit University, Kdz. Ereğli, Zonguldak, Turkey \\ ${ }^{b}$ Physics Department, Faculty of Arts and Sciences, Uludag University, Bursa, Turkey \\ ${ }^{c}$ Physics Department, Faculty of Arts and Sciences, Bülent Ecevit University, Zonguldak, Turkey
}

The distributions of ${ }^{226} \mathrm{Ra},{ }^{232} \mathrm{Th},{ }^{40} \mathrm{~K}$ and ${ }^{137} \mathrm{Cs}$ activity concentrations were determined using a high-purity germanium detector in uncultivated surface soil samples collected from Zonguldak. The range of ${ }^{226} \mathrm{Ra},{ }^{232} \mathrm{Th},{ }^{40} \mathrm{~K}$ and ${ }^{137} \mathrm{Cs}$ activity concentrations varied from $10.5 \pm 2.0$ to $98.0 \pm 4.3 \mathrm{~Bq} \mathrm{~kg}^{-1}$ (mean value $28.8 \pm 4 \mathrm{~Bq} \mathrm{~kg}^{-1}$ ), from $12.9 \pm 3.4$ to $53.2 \pm 5.1 \mathrm{~Bq} \mathrm{~kg}^{-1}$ (mean value $29.6 \pm 3 \mathrm{~Bq} \mathrm{~kg}^{-1}$ ), from $190 \pm 22$ to $808 \pm 43 \mathrm{~Bq} \mathrm{~kg}^{-1}$ (mean value $395 \pm 31 \mathrm{~Bq} \mathrm{~kg}^{-1}$ ) and from $<0.5$ to $47.1 \pm 3.8 \mathrm{~Bq} \mathrm{~kg}^{-1}$ (mean value $12.5 \pm 2 \mathrm{~Bq} \mathrm{~kg}^{-1}$ ), respectively. In addition, the mean outdoor absorbed dose rates in air (terrestrial, terrestrial+cosmic), annual effective dose equivalent, radium equivalent activity and external hazard index were found to be $48 \mathrm{nGy} \mathrm{h}^{-1}$ (terrestrial), $56 \mathrm{nGy} \mathrm{h}^{-1}$ (terrestrial+cosmic), $58 \mu \mathrm{Sv} \mathrm{y}^{-1}, 101 \mathrm{~Bq} \mathrm{~kg}^{-1}$ and 0.27 , respectively. The evaluated excess lifetime cancer risks (ELCRs) varied from $0.13 \times 10^{-3}$ to $0.36 \times 10^{-3}$ with a mean value of $0.20 \times 10^{-3}$.

DOI: 10.12693/APhysPolA.132.1122

PACS/topics: 07.88.+y, 89.60.-k

\section{Introduction}

Environmental natural gamma radiation is formed from terrestrial and cosmic sources. The terrestrial component of the natural background radiation depends on the compositions of soil and rocks containing natural and artificial radionuclides [1, 2]. An important contribution to total dose from natural sources comes from terrestrial radionuclides, such as ${ }^{238} \mathrm{U},{ }^{232} \mathrm{Th}$ and ${ }^{40} \mathrm{~K}$, existing in soil $[3,4]$. Since these radionuclides are not uniformly distributed, the knowledge of their distribution in soil and rocks, due to the difference in the geological structure of the region, plays an important role in radiation protection and measurement. Besides naturally occurring radionuclides, many radionuclides of artificial origin have been released into the environment by different processes. The isotope ${ }^{137} \mathrm{Cs}$ is one of them and it is produced anthropogenically by several types of nuclear activities. Cosmic radiation originates from cosmic rays, whose contribution to background changes mainly with altitude and latitude.

Background radiation measurement in Zonguldak province was previously performed in surface soils around the Çatalağzi coal-fired power plant in Zonguldak, by Aytekin and Baldık [5, 6]. The main objective of this study was to identify and to determine natural radionuclide activity concentrations in soil samples collected from 22 locations around the province of Zonguldak and to evaluate the annual effective dose and lifetime cancer

*corresponding author; e-mail: korayabdullah@gmail.com risks from outdoor terrestrial radiation. In addition, the natural gamma radiation coming from terrestrial radionuclides in air was also investigated in the Zonguldak region. To the researcher's knowledge, this is the first study to assess the level of the background radiation in Zonguldak province.

Zonguldak province is situated between $41^{\circ} 00^{\prime \prime}$ $41^{\circ} 35^{\prime \prime} \mathrm{N}$ latitude and $31^{\circ} 18^{\prime \prime}-32^{\circ} 19^{\prime \prime} \mathrm{E}$ longitude. The Zonguldak Basin, which contains a thick Carboniferous clastic sequence with several coal seams, is located in the northwestern Turkey on the Black Sea coast. It is predicted that the coal reserves in Zonguldak coal basin are about 1.1 billion tons of coal and from a mining operations point of view, Zonguldak Basin is the most important production area in Turkey [7]. These features make Zonguldak an interesting candidate for radiological studies.

\section{Materials and methods}

The sampling procedure was done as described by Akkaya et al. [8]. Sampling locations are shown in Fig. 1.

Prepared soil samples were placed in acrylic cylindrical containers with dimensions of $6 \mathrm{~cm} \times 5 \mathrm{~cm}$. The containers were closed and stored for a month in order to achieve the radioactive equilibrium between ${ }^{226} \mathrm{Ra}$ and its daughter element $\left({ }^{222} \mathrm{Rn}\right)[9] .{ }^{40} \mathrm{~K},{ }^{232} \mathrm{Th},{ }^{226} \mathrm{Ra}$ and ${ }^{137} \mathrm{Cs}$ activity concentrations were measured using a p-type coaxial HP Ge detector (ORTEC/GEM110P4) with a relative efficiency of $107.7 \%$ and resolution of $1.92 \mathrm{keV}$ at $1.33 \mathrm{MeV}$ (with associated electronics produced by EG\&G Ortec). The detector was surrounded by a $9.25 \mathrm{~cm}$ thick lead shield. For activity of ${ }^{238} \mathrm{U}$ and ${ }^{232} \mathrm{Th}$ the following gamma lines were used; ${ }^{238} \mathrm{U}$ : $186 \mathrm{keV}$ 


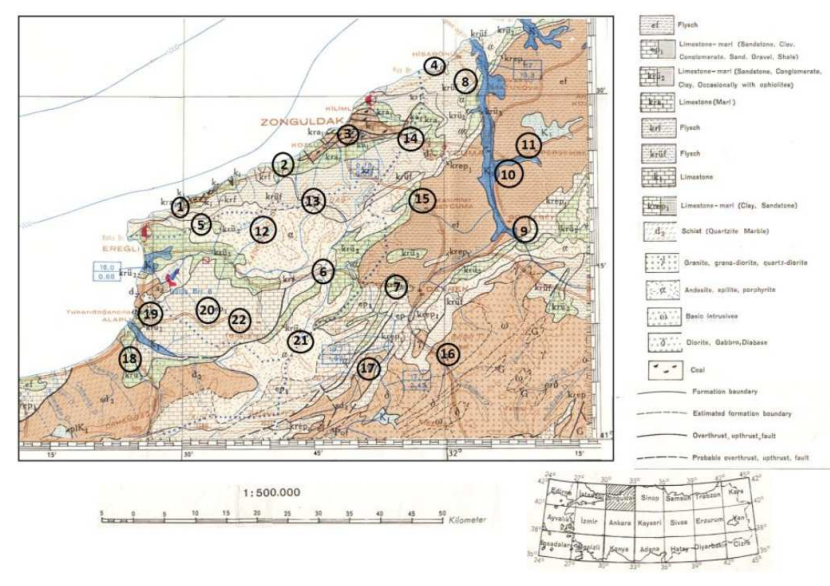

Fig. 1. Study area and sampling sites.

$\left({ }^{226} \mathrm{Ra}\right), 295 \mathrm{keV}$ and $352 \mathrm{keV}\left({ }^{214} \mathrm{~Pb}\right), 609 \mathrm{keV}, 1120 \mathrm{keV}$ and $1764 \mathrm{keV}\left({ }^{214} \mathrm{Bi}\right) ;{ }^{232} \mathrm{Th}: 583 \mathrm{keV}\left({ }^{208} \mathrm{Tl}\right), 911 \mathrm{keV}$ $\left({ }^{228} \mathrm{Ac}\right)$. The activity of ${ }^{40} \mathrm{~K}$ was determined directly by its $1460 \mathrm{keV}$ gamma line and the activity of ${ }^{137} \mathrm{Cs}$ was determined by its $662 \mathrm{keV}$ gamma transition. The detector calibration was performed using standards in radioactive equilibrium, purchased from International Atomic Energy Agency. The minimum detectable activity of the detector for ${ }^{226} \mathrm{Ra},{ }^{232} \mathrm{Th},{ }^{40} \mathrm{~K}$ and ${ }^{137} \mathrm{Cs}$ was found to be $2.2,6.7,15.5$ and $0.5 \mathrm{~Bq} \mathrm{~kg}^{-1}$, respectively, for 20000 s counting time.

The outdoor gamma radiation levels were measured by a portable dose rate meter (Fluke Victoreen survey meter, connected with a 489-55 model $1.5^{\prime \prime} \times 1.5^{\prime \prime} \mathrm{NaI}(\mathrm{Tl})$ scintillation detector, optically coupled to PMT, as described by Akkaya et al. [10].

\section{Results and discussion}

The activity concentrations of the radionuclides in 22 surface soil samples are given in Table I. The activity concentrations of ${ }^{226} \mathrm{Ra},{ }^{232} \mathrm{Th}$ and ${ }^{40} \mathrm{~K}$ have varied in the range from $10.5 \pm 2.0$ to $98.0 \pm 4.3 \mathrm{~Bq} \mathrm{~kg}^{-1}$, from $12.9 \pm 3.4$ to $53.2 \pm 5.1 \mathrm{~Bq} \mathrm{~kg}^{-1}$, and from $190 \pm 22$ to $808 \pm 43 \mathrm{~Bq} \mathrm{~kg}^{-1}$, respectively. The average activity concentrations found in the study are around the world averages, reported by UNSCEAR [11] as 35, 30 and $400 \mathrm{~Bq} \mathrm{~kg}^{-1}$ for ${ }^{226} \mathrm{Ra},{ }^{232} \mathrm{Th}$ and ${ }^{40} \mathrm{~K}$, respectively.

The two highest ${ }^{226} \mathrm{Ra}$ activity concentrations were found as 98.0 and $59.2 \mathrm{~Bq} \mathrm{~kg}^{-1}$ for the samples collected from the the Kokaksu and Buruncuk respectively. At the same time, the two biggest measurements for ${ }^{232} \mathrm{Th}$ are 53.2 and $51.4 \mathrm{~Bq} \mathrm{~kg}^{-1}$, from the Buruncuk and Kokaksu respectively. The reason for the high ${ }^{226} \mathrm{Ra}$ and ${ }^{232} \mathrm{Th}$ activity concentrations can be explained by the fact that there are coaly clastic rocks in these areas. It is known that coals sometimes include high contents of natural radioactive elements ( $\mathrm{U}, \mathrm{Th}$, and their decay products) and, in some cases, concentrate considerable amounts of the uranium $[12,13]$. The four highest ${ }^{40} \mathrm{~K}$ activity concentration are $808,561,561$ and $541 \mathrm{~Bq} \mathrm{~kg}^{-1}$, which were found in soil samples collected from the Soğanliyörük, Beycuma, İsabeyli and Alpaslan respectively. The reason of the high ${ }^{40} \mathrm{~K}$ activity concentrations can be explained with the existence of limestone and clay in this region. In general, limestones, clays and shales contain relatively high concentration of potassium [14, 15].

The ${ }^{137} \mathrm{Cs}$ activity concentration ranges from $<0.5$ to $47.1 \pm 3.8 \mathrm{~Bq} \mathrm{~kg}^{-1}$. It was found that ${ }^{137} \mathrm{Cs}$ activities of the soil samples collected from Kokaksu, Düzpelit and İsabeyli are higher than activities of the others. ${ }^{137} \mathrm{C}$ is a fission product. It has been spread by a nuclear explosion or a reactor accident. The northwest of Turkey was also contaminated because of Chernobyl reactor accident. Due to the lack of data before the Chernobyl accident, it is not possible to compare ${ }^{137} \mathrm{Cs}$ concentrations originating from the previous nuclear weapon tests and Chernobyl accident by means of the data obtained for Zonguldak.

Absorbed dose rate in air (ADRA) depends on the activity concentrations of ${ }^{238} \mathrm{U},{ }^{232} \mathrm{Th}$ and ${ }^{40} \mathrm{~K}$ natural radioisotopes ADRA $\left(\mathrm{nGy} \mathrm{h}^{-1}\right)$ was calculated using the following relation [11]:

$\mathrm{ADRA}=0.462 C_{\mathrm{U}}+0.604 C_{\mathrm{Th}}+0.041 C_{\mathrm{K}}$,

where ADRA is the dose rate in air at $1 \mathrm{~m}$ above the ground, and $C_{\mathrm{U}}, C_{\mathrm{Th}}$ and $C_{\mathrm{K}}$ are the mean activity concentrations of ${ }^{238} \mathrm{U},{ }^{232} \mathrm{Th}$ and ${ }^{40} \mathrm{~K}$ in $\mathrm{Bq} \mathrm{kg}^{-1}$ of the soil sample, respectively.

ADRA values and the measured dose rates are given in Table I. The obtained mean absorbed dose was found to be $48 \mathrm{nGy} \mathrm{h}^{-1}$. The average measured outdoor gamma dose rate (terrestrial and cosmic ray) is $56 \mathrm{nGy} \mathrm{h}^{-1}$, which is higher than the average of the calculated. This difference is to be expected since the absorbed doses are calculated only for outdoor terrestrial gamma radiation, whereas the measured doses have cosmic contributions as well. The result obtained by the study is near the world average value $\left(\sim 51 \mathrm{nGy} \mathrm{h}^{-1}[11]\right)$.

$\mathrm{AEDE}=\mathrm{ADRA} \times \mathrm{DCF} \times \mathrm{OF} \times \mathrm{T}$,

where, DCF is the dose conversion factor $\left(0.7 \mathrm{~Sv} \mathrm{~Gy}^{-1}\right)$, $\mathrm{OF}$ is the outdoor occupancy factor $(0.2)$ and $\mathrm{T}$ is the time factor $\left(8760 \mathrm{hy}^{-1}\right)$ [11]. AEDE values are given in Table I. The calculated annual mean effective dose equivalent was found to be $58 \mu \mathrm{Svy}^{-1}$.

To assess the radiological risk, it is useful to calculate an index called the Radium equivalent activity, $\mathrm{Ra}_{\mathrm{eq}}$ in $\mathrm{Bq} \mathrm{kg}^{-1}$. It is calculated through the following relation [16].

$$
\mathrm{Ra}_{\mathrm{eq}}=C_{\mathrm{Ra}}+1.43 C_{\mathrm{Th}}+0.077 C_{\mathrm{K}},
$$

where $C_{\mathrm{Ra}}, C_{\mathrm{Th}}$ and $C_{\mathrm{K}}$ are the mean activity concentrations of ${ }^{226} \mathrm{Ra},{ }^{232} \mathrm{Th}$ and ${ }^{40} \mathrm{~K}$ (in $\mathrm{Bq} \mathrm{kg}^{-1}$ ) of the soil sample, respectively. Values of $\mathrm{Ra}_{\mathrm{eq}}$, calculated using Eq. (3) are given in Table I. The calculated mean radium equivalent activity was found to be $101 \mathrm{~Bq} \mathrm{~kg}^{-1}$. The recommended maximum value of $\mathrm{Ra}_{\mathrm{eq}}$ is $370 \mathrm{~Bq} \mathrm{~kg}^{-1}$ [16]. All $\mathrm{Ra}_{\mathrm{eq}}$ values calculated in this study are lower than the recommended value. 
$H_{\mathrm{ex}}$, is defined as the external hazard index, and it is given by the following equation.

$$
H_{\mathrm{ex}}=\frac{C_{\mathrm{Ra}}}{370}+\frac{C_{\mathrm{Th}}}{259}+\frac{C_{\mathrm{K}}}{4810},
$$

$C_{\mathrm{Ra}}, C_{\mathrm{Th}}$ and $C_{\mathrm{K}}$ have the same meaning as in Eq. (3). Calculated $H_{\mathrm{ex}}$ values are given in Table I. The value of $H_{\mathrm{ex}}$ must be less than unity [17-19]. All calculated values are lower than 1 .

TABLE I

${ }^{226} \mathrm{Ra},{ }^{23} 2 \mathrm{Th},{ }^{40} \mathrm{~K}$ and ${ }^{137} \mathrm{Cs}$ activity concentrations, absorbed dose rates in air, AEDE, radium equivalent activity, external hazard index and excess lifetime cancer risk in soil samples collected from Zonguldak.

\begin{tabular}{|c|c|c|c|c|c|c|c|c|c|c|}
\hline \multirow[b]{2}{*}{$\begin{array}{c}\text { (Sampling code) } \\
\text { Sampling areas }\end{array}$} & \multirow[b]{2}{*}{$\begin{array}{c}{ }^{226} \mathrm{Ra} \\
{\left[\mathrm{Bq} \mathrm{kg}^{-1}\right]}\end{array}$} & \multirow[b]{2}{*}{$\begin{array}{c}{ }^{232} \mathrm{Th} \\
{\left[\mathrm{Bq} \mathrm{kg}^{-1}\right]}\end{array}$} & \multirow[b]{2}{*}{$\begin{array}{c}{ }^{40} \mathrm{~K} \\
{\left[\mathrm{~Bq} \mathrm{~kg}^{-1}\right]}\end{array}$} & \multirow[b]{2}{*}{$\begin{array}{c}{ }^{137} \mathrm{Cs} \\
{\left[\mathrm{Bq} \mathrm{kg}^{-1}\right]}\end{array}$} & \multicolumn{2}{|c|}{ ADRA $\left(\right.$ nGy h $\left.^{-1}\right)$} & \multirow[b]{2}{*}{$\begin{array}{c}\mathrm{AEDE} \\
{\left[\mu \mathrm{Svy}^{-1}\right]}\end{array}$} & \multirow[b]{2}{*}{$\begin{array}{c}\mathrm{Ra}_{\mathrm{eq}} \\
{\left[\mathrm{Bq} \mathrm{kg}^{-1}\right]}\end{array}$} & \multirow[b]{2}{*}{$H_{\mathrm{ex}}$} & \multirow[b]{2}{*}{$\begin{array}{c}\text { ELCR } \\
\text { terrestrial }\end{array}$} \\
\hline & & & & & Terrestrial & $\begin{array}{l}\text { Terrestrial } \\
\text { and cosmic }\end{array}$ & & & & \\
\hline (1) Buruncuk & $59.2 \pm 3.2$ & $53.2 \pm 5.1$ & $451 \pm 31$ & $12.0 \pm 2.6$ & 78 & 80 & 96 & 170 & 0.46 & $0.34 \times 10^{-3}$ \\
\hline (2) Ilıksu & $18.4 \pm 2.0$ & $19.7 \pm 3.2$ & $205 \pm 23$ & $<0.5$ & 29 & 52 & 36 & 62 & 0.17 & $0.12 \times 10^{-3}$ \\
\hline (3) Kokaksu & $98.0 \pm 4.3$ & $51.4 \pm 5.2$ & $343 \pm 30$ & $20.9 \pm 3.0$ & 91 & 80 & 111 & 198 & 0.53 & $0.39 \times 10^{-3}$ \\
\hline (4) Türkali & $11.2 \pm 2.0$ & $13.8 \pm 3.5$ & $279 \pm 25$ & $<0.5$ & 25 & 37 & 31 & 52 & 0.14 & $0.11 \times 10^{-3}$ \\
\hline (5) Soğanlıyörük & $35.4 \pm 2.8$ & $43.8 \pm 5.0$ & $808 \pm 43$ & $13.8 \pm 2.8$ & 77 & 82 & 94 & 160 & 0.43 & $0.33 \times 10^{-3}$ \\
\hline (6) Düzpelit & $15.9 \pm 2.2$ & $13.1 \pm 3.7$ & $238 \pm 27$ & $47.1 \pm 3.8$ & 25 & 48 & 31 & 53 & 0.14 & $0.11 \times 10^{-3}$ \\
\hline (7) İsabeyli & $32.7 \pm 2.7$ & $38.8 \pm 4.8$ & $541 \pm 36$ & $26.8 \pm 3.1$ & 61 & 64 & 75 & 130 & 0.35 & $0.26 \times 10^{-3}$ \\
\hline (8) Alpaslan & $28.5 \pm 2.6$ & $30.9 \pm 4.6$ & $484 \pm 30$ & $13.5 \pm 2.4$ & 52 & 58 & 64 & 110 & 0.30 & $0.22 \times 10^{-3}$ \\
\hline (9) Gaziler & $16.1 \pm 2.2$ & $20.9 \pm 4.3$ & $310 \pm 27$ & $6.7 \pm 2.1$ & 33 & 46 & 40 & 70 & 0.19 & $0.14 \times 10^{-3}$ \\
\hline (10) Geriş & $24.2 \pm 2.4$ & $31.2 \pm 4.4$ & $399 \pm 31$ & $15.7 \pm 2.4$ & 47 & 49 & 57 & 100 & 0.27 & $0.20 \times 10^{-3}$ \\
\hline (11) Kerimler & $26.6 \pm 2.5$ & $22.2 \pm 4.5$ & $417 \pm 32$ & $10.8 \pm 2.5$ & 43 & 49 & 53 & 90 & 0.24 & $0.18 \times 10^{-3}$ \\
\hline (12) Dağlıca & $30.5 \pm 2.5$ & $31.8 \pm 4.5$ & $202 \pm 27$ & $9.9 \pm 2.4$ & 42 & 52 & 51 & 92 & 0.25 & $0.18 \times 10^{-3}$ \\
\hline (13) Balçıklı & $21.7 \pm 2.4$ & $31.7 \pm 4.6$ & $332 \pm 30$ & $7.8 \pm 2.4$ & 43 & 53 & 53 & 93 & 0.25 & $0.18 \times 10^{-3}$ \\
\hline (14) Sofular & $38.4 \pm 2.7$ & $43.0 \pm 4.7$ & $440 \pm 30$ & $14.7 \pm 2.5$ & 62 & 84 & 76 & 134 & 0.36 & $0.27 \times 10^{-3}$ \\
\hline (15) Beycuma & $29.2 \pm 2.5$ & $32.8 \pm 4.3$ & $561 \pm 33$ & $5.9 \pm 2.2$ & 57 & 54 & 70 & 119 & 0.32 & $0.24 \times 10^{-3}$ \\
\hline (16) Gürbüzler & $15.2 \pm 1.9$ & $12.9 \pm 3.4$ & $190 \pm 22$ & $8.0 \pm 2.0$ & 23 & 29 & 28 & 48 & 0.13 & $0.10 \times 10^{-3}$ \\
\hline (17) Ĕ̆erci & $15.1 \pm 1.9$ & $15.9 \pm 3.5$ & $289 \pm 25$ & $14.3 \pm 2.1$ & 29 & 37 & 35 & 60 & 0.16 & $0.12 \times 10^{-3}$ \\
\hline (18) Findıklı & $10.5 \pm 2.0$ & $19.2 \pm 3.8$ & $341 \pm 28$ & $7.6 \pm 2.1$ & 31 & 38 & 38 & 64 & 0.17 & $0.13 \times 10^{-3}$ \\
\hline (19) Hüseyinli & $17.8 \pm 1.9$ & $19.0 \pm 3.5$ & $454 \pm 29$ & $<0.5$ & 39 & 50 & 47 & 80 & 0.22 & $0.17 \times 10^{-3}$ \\
\hline (20) Işıklı & $30.5 \pm 2.4$ & $36.4 \pm 4.3$ & $483 \pm 33$ & $9.5 \pm 2.2$ & 56 & 59 & 69 & 120 & 0.32 & $0.24 \times 10^{-3}$ \\
\hline (21) Uludă & $31.1 \pm 2.5$ & $33.5 \pm 4.2$ & $454 \pm 31$ & $14.9 \pm 2.4$ & 54 & 70 & 66 & 114 & 0.31 & $0.23 \times 10^{-3}$ \\
\hline (22) Ormanlı & $26.7 \pm 2.3$ & $35.2 \pm 3.9$ & $468 \pm 32$ & $15.9 \pm 2.3$ & 53 & 62 & 65 & 113 & 0.31 & $0.23 \times 10^{-3}$ \\
\hline Mean & $28.8 \pm 4$ & $29.6 \pm 3$ & $395 \pm 31$ & $12.5 \pm 2$ & 48 & 56 & 58 & 101 & 0.27 & $0.20 \times 10^{-3}$ \\
\hline
\end{tabular}

Excess lifetime cancer risk (ELCR) was calculated using Eq. (5)

$\mathrm{ELCR}=\mathrm{AEDE} \times \mathrm{DL} \times \mathrm{RF}$,

where DL is duration of life (70 year) and RF is risk factor $\left(\mathrm{Sv}^{-1}\right)$, fatal cancer risk per Sievert. For stochastic effects, ICRP 60 [20] uses values of 0.05 for the public. ELRC values calculated from Eq. (5) are given in Table I.

When life expectancy was taken as 70 years, the mean lifetime outdoor gamma radiation was calculated as $4.06 \mathrm{mSv}$ (terrestrial) and $4.81 \mathrm{mSv}$ (terrestrial and cosmic). These values yielded a lifetime cancer risk of $0.20 \times 10^{-3}$ (terrestrial) and $0.24 \times 10^{-3}$ (terrestrial and cosmic). According to UNSCEAR [11], the average ELRC value in the world is $0.25 \times 10^{-3}$ (terrestrial) and $0.29 \times 10^{-3}$ (terrestrial and cosmic). The results obtained by the study are less than the world average values.

\section{Conclusions}

The activity concentrations of ${ }^{226} \mathrm{Ra},{ }^{232} \mathrm{Th},{ }^{40} \mathrm{~K}$ and ${ }^{137} \mathrm{Cs}$ were determined in uncultivated surface soil samples collected from Zonguldak. From the measured values, the mean outdoor gamma ADRA, annual effective gamma dose equivalent (AEDE), radium equivalent activity $\left(\mathrm{Ra}_{\mathrm{eq}}\right)$ and external hazard index $\left(H_{\mathrm{ex}}\right)$ were calculated. The results presented in this study are at normal levels, except for some locations.

In order to evaluate the health hazard, especially various types of cancer, it is important to determine the environmental radioactivity level. This research indicats that the average lifetime risks of cancer of the Zonguldak are below the worldwide range, even though there are some extreme values. This study contributes to the database of the radioactivity level and lifetime risks of 
cancer in the Province of Zonguldak. The results may also be used as a reference data for monitoring possible radioactivity pollution in future.

\section{Acknowledgments}

The authors wish to thank Scientific Research Projects Unit of Bülent Ecevit University (Project No: 201376962555-01)

\section{References}

[1] P. Otansev, G. Karahan, E. Kam, I. Barut, H. Taskin, Radiat. Prot. Dosim. 148, 227 (2012).

[2] N. Zaim, A.B. Tugrul, H. Atlas, B. Buyuk, E. Demir, N. Baydogan, N. Altınsoy, Acta Phys. Pol. A 130, 64 (2016).

[3] A. Coşkun, B. Çetin, Acta Phys. Pol. A 130, 309 (2016).

[4] M.C. Boz, F. Öner, B. Mavi, Acta Phys. Pol. A 128, B-360 (2015).

[5] H. Aytekın, R. Baldık, Turkish J. Eng. Env. Sci. 32, 101 (2008).

[6] H. Aytekın, R. Baldık, Fresenius Environ. Bull. 20, 1642 (2011).

[7] C.Ö. Karacan, E. Okandan, Int. J. Coal Geol. 44 109 (2000).

[8] G. Akkaya, G. Kaynak, A. Kahraman, O. Gurler, Radiat. Prot. Dosim. 152, 376 (2012).
[9] B. Çetin, F. Öner, İ. Akkurt, Acta Phys. Pol. A 130, 475 (2016).

[10] G. Akkaya, A. Kahraman, A. Koray, G. Kaynak, J. Radiol. Prot. 36, 490 (2016).

[11] UNSCEAR, Report to the General Assembly, with scientific annexes, Sources and effects of ionizing radiation, New York: United Nations Scientific Committee on the Effects of Atomic Radiation, 2000.

[12] D.J. Swaine, Trace Elements in Coal, Betterworth \& Co., London 1990, p. 192.

[13] S.I. Arbuzov, A.V. Volostnov, L.P. Rikhvanov, A.M. Mezhibor, S.S. Ilenok, Int. J. Coal Geol. 86, 318 (2011).

[14] S.M. Testa, Geological Aspects of Hazardous Waste Management, CRC Press, USA 1994, p. 206.

[15] N.A. Uyanık, Z. Öncü, O. Uyanık, M. Bozcu, İ. Akkurt, K. Günoğlu, F. Yağmurlu, Acta Phys. Pol. A 128, B-438 (2015).

[16] J. Beretka, P.J. Mathew, Health Phys. 48, 87 (1985).

[17] R. Krieger, Betonwerk Fertigteil Techn. 47, 468 (1981).

[18] B. Mavi, I. Akkurt, Rad. Phys. Chem. 79, 933 (2010).

[19] N.A. Uyanik, Z. Öncü, O. Uyanik, İ. Akkurt, Acta Phys. Pol. A 128, B-441 (2015).

[20] ICRP, International Commission on Radiological Protection, ICRP Publication 60, Ann. ICRP 21. Recommendations of the International Commission on Radiological Protection, 1990. 